Archives of Agriculture and Environmental Science

\title{
Analysis of economic valuation of environmental damage due to sand mine in Gumulung Tonggoh, Cirebon District, West Java Province, Indonesia
}

\author{
Basuki Wasis ${ }^{1^{*}}$ (D) ,Bambang Hero Saharjo ${ }^{1}$, Fitri Kusumadewi ${ }^{1}$, Nur Hikmah Utami ${ }^{1}$ and \\ Muhammad Hafiz Wasis Putra ${ }^{2}$ \\ ${ }^{1}$ Department of Silviculture, Faculty of Forestry, Institut Pertanian Bogor. Darmaga, Bogor 16680, West Java, INDONESIA \\ ${ }^{2}$ Departement of Environment Economic, Faculty of Management and Economic, Institut Pertanian Bogor, Darmaga, Bogor 16680, \\ West Java, INDONESIA \\ *Corresponding author's E-mail: basuki_wasis@yahoo.com
}

\section{ARTICLE HISTORY}

Received: 12 November 2018

Accepted: 26 November 2018

\section{Keywords}

Environmental damage

Indonesia

Sand mine

Soil physical and chemical properties West Java Province

\section{ABSTRACT}

The sand mines at Gumulong Tonggoh in Cirebon Regency use an open mining system. Open mining activities can cause environmental damage and economic losses. The present investigation was carried out to analyze the economic valuation of environmental damage due to sand mine in Gumulung Tonggoh, Cirebon District, West Java Province, Indonesia. The sampling method and environmental damage analysis use purposive sampling. Data of laboratory tests of soil physical, chemical and biological properties was analyzed by statistical tests. The economic method of environmental damage valuation uses the Ministry of Environment guidelines (2006). Sand mining activities cause soil and environmental damage to the soil (soil solum, bulk density, permeability, and soil fauna) and vegetation (land cover). However, sand mining has caused changes in soil properties, namely a significant increase in bulk density of $+0.49(53.85 \%)$, reduction in porosity of 18.26 (27.79\%), decrease in Ca of -11.17 (60.48\%), a decrease in $\mathrm{Mg}$ of -5.76 (60.95\%), a decrease in CEC of -19.06 (79.88\%) and a decrease in the total microorganism of 47.00 (83.19). The total of economic valuation for environmental damage due to sand mining is Rp. $39,349,860,000$. Therefore, the sand mining significantly contributed the environmental damage in the Gumulung Tonggoh, Cirebon District, West Java Province in Indonesia.

(C)2018 Agriculture and Environmental Science Academy

Citation of this article: Wasis, B., Saharjo, B.H., Kusumadewi, F., Utami, N.H. and Putra, M.H.W. (2018). Analysis of economic valuation of environmental damage due to sand mine in Gumulung Tonggoh, Cirebon District, West Java Province, Indonesia. Archives of Agriculture and Environmental Science, 3(4): 360-366, https://dx.doi.org/10.26832/24566632.2018.030405

\section{INTRODUCTION}

One of the mines that is frequently contained in Indonesia is sand mines, for sand material is one of the main raw materials for civil buildings such as houses, buildings, roads, bridges, ports, dams and others. Sand material is used to meet the needs of local communities and outside the area. Location of Gumulung Tonggoh in Cirebon Regency is one of the regions that has abundant natural resources in the form of sand. Sand mining generally uses an open mining system. Open mining is the activity of mining or excavating minerals whose processes are directly related to open air and the loss of soil solum (Kusumadewi, 2012; Wasis et al., 2018). Open pit mining activities generally consist of land clearing, overburden stripping, demolition, selection, loading, transporting, reducing, washing / refining, marketing, and reclamation. The negative impact of sand mining with the open pit system is mainly due to environmental degradation, changes in environmental geology including aesthetic conditions, topography, slope, elevation, bedrock disclosure, erosion, sedimentation, degraded groundwater quality and quantity, decreased in soil productivity, disruption to flora and fauna; micro-climate change, as well as various socio-economic problems. This has become one of the contributors to the negative impacts on future development. If the carrying capacity of the environment has been exceeded, then the function of ecosystems will be 
disrupted and damaged causing a loss of environmental economics (Dumairy, 1992; Kusumadewi, 2012; Fauzi, 2014; Wasis, 2017; Wasis et al., 2017).

Based on an assessment carried out by the Cirebon Regency Environmental Service, various violations and misuse of licenses were carried out by mining operators operating unproperly so that they had the effect of environmental damage. In addition, environmental damage will cause environmental losses, so it is necessary to calculate environmental economic losses that occured due to sand mining. The purpose of the study was to analyze soil damage due to sand mining activities and economic valuation of environmental damage in Gumulung Tonggoh Village, Astanajapura District, Cirebon Regency, West Java Province, Indonesia.

\section{MATERIALS AND METHODS}

\section{About the study area}

Field research and laboratory analysis were carried out in June - December 2006 and July to August 2011 at Gumulung Tonggoh Cirebon Regency Gumulung Tonggoh Cirebon Regency, West Java Province, Indonesia. Analysis of soil damage and economic valuation of environmental damage is carried out in July - August 2018. The research materials used were soil and vegetation originating from the sand mining area (area 2 ha), agricultural land and secondary forest from Gumulung Tonggoh, Cirebon Regency.

\section{Preparation of forest observation plots}

Measurements and observations of potential timber were conducted on 20 meters $\times 20$ meters for trees (Agroforestry and forest plantation) (Kusmana and Istomo, 1995; Laar and Akca, 1997; Soerianegara and Indrawan, 2005). The measurement results are recorded in tally sheets that have been distinguished in each plot size.

\section{Soil sampling}

Soil sampling was done by purposive sampling on mined land, rice land and secondary forest land. The study was conducted on three plots on ex-mining land, rice land, and forest plantation land of $20 \mathrm{~m} \times 20 \mathrm{~m}$ (0.04 ha) each. Within the mine, rice land and forest plantation land plots, three subplots of $1 \mathrm{~m} \times 1 \mathrm{~m}$ were placed randomly for ground sampling. Then, the soil sample is composited. Soil sampling for the chemical properties and biological properties of soil is taken evenly on the soil surface of $0-20 \mathrm{~cm}$. Soil taking is done by composite as much as $1 \mathrm{~kg}$. Soil sampling for soil physical properties was done at ground level of $0-20 \mathrm{~cm}$. Intake of soil is done intactly by using ring sample with diameter of $7 \mathrm{~cm}$ with height of $5 \mathrm{~cm}$.

\section{Soil analysis}

The soil taken from the field is then analyzed in the laboratory. Soil analysis for physical properties (limbak density, porosity, drainage pore, available water and permeability), chemical properties (soil $\mathrm{pH}, \mathrm{C}$-organic, nitrogen $(\mathrm{N})$, phosphorus $(\mathrm{P})$, calcium (Ca), magnesium(Mg), and Cation exchange capacity), and biological properties (total microorganisms, total fungi, solvent $\mathrm{P}$ bacteria and soil respiration) were analyzed following standard methods (AOAC, 2005). The location of sample in exmining land, rice land, and agroforestry land is located side by side, so the difference of soil type, topography, climate and other is relatively assumed the same.

\section{Data analysis}

Data of laboratory test of soil physical and chemical properties were analyzed by statistical -test. Descriptive analysis is done by describing the average value of each variable on three replicates and categorizing based on the criterion of soil properties. Meanwhile, statistical analysis was done by using $\mathrm{t}$-Test at $95 \%$ confidence interval. This is to determine the impact on soil physical and chemical properties as a result of the forest encroachment. Software used in statistical analysis is SPS 16.00 (Mattjik and Sumertajaya, 2013; Stell and Torries, 1991; Wibisono, 2009). Analysis of soil damage using government regulations (Peraturan Pemerintah) number 150 / 2000, Minister of Environment Decree Number: KEP-43 / MENLH / $10 / 1996$ and valuation economics analysis of environmental damage using the $2006 \mathrm{KLH}$ (Kementerian Lingkungan Hidup) for environmental economic calculation guidelines.

\section{RESULTS AND DISCUSSION}

Soil damage and environmental due to the sand mine

\section{General conditions of research location}

Environmental damage due to sand mining (natural rock, sand and soil extraction) was on cultivated land, plantations and mixed gardens of Gumulung Tonggoh Village, Astanajapura SubDistrict, Cirebon Regency, West Java Province, on coordinates $S$ $06.80047^{\circ}$ and $\mathrm{E} 108.60292^{\circ}$ covering 2 ha. The sand mining case has violated the Cirebon District Regent's permission in the Cirebon Regency Regional Regulation Number 80 of 2001 concerning the management of regional mining in conjunction with Kep. Regent No. 19 of 2002 concerning management of regional mining (Letter of Closing of Cirebon Regent). The permitted sand mining area is 0.9 ha (not yet mined), but sand mining activities have reached 2 ha. This sand mining field has a thin soil solum of around $30-50 \mathrm{~cm}$ and the lower layer is rock and sand this area is very suitable for a water catchment area yet it is prone to erosion and landslides. Water content in mixed plantations and gardens in the study location was 20.05 $\pm 0.58 \%$. Stages of sand and stone mines are carried out through felling trees (kapok, petai china, teak, mango), excavating soil, extracting sand, separating or refining sand and stone with clay material, organic material and other materials, accumulating sand and selling sand and stone. The sand mining products sold are sand and rock (split).

The sand mining activity has caused a loss of $0.5 \mathrm{~m}$ of soil layer (horizon $\mathrm{A}$ and horizon $\mathrm{B}$ ) and $6.5 \mathrm{~m}$ thick rock, consequently in the former sand mining area the soil solum is lost and ponds 
with a depth of about $2-4 \mathrm{~m}$ are found. The results showed that the $25 \mathrm{~cm}$ soil formation rate was needed for 100 years (Hardjowigeno, 2007), thus the time needed for soil formation lost due to sand mining as usual would take around 50 years. Based on this, there has to soil parameters (Ministry of Environment Decree Number: KEP-43 / MENLH / 10/1996; PP Number 150 of 2000). The land cover of the research area is in hilly areas (ridge) with cultivated and mixed gardens, and on slopes and valleys found agricultural land. In cultivated land (owned by the community), two dominant tree species were planted, namely Swietenia mahagoni and Tectona grandis. While in mixed gardens, it is found sengon, mahogany, teak, mango and others. The government has provided guidance on the former sand mining land that needs reclamation by planting trees such as mahogany and teak. Based on the results of research in secondary forest, biomass for mahogany is 64.4 tons / ha and teak is 42.22 tons / ha. Whereas in the former sand mining area, no tree vegetation and agricultural crops have been found because they have been cut down and the soil solum has also been lost due to the peeling of the soil. Based on this, there has been damage to vegetation parameters (Ministry of Environment Decree Number: KEP-43 / MENLH / 10/1996). For more details, it is shown in Table 1 and Figure 1.

The loss of vegetation from garden and agricultural land due to sand mining causes loss of function of the water system, carbon uptake, destruction of soil flora and fauna, loss of wood, erosion, river sedimentation and river pollution (Sari et al., 2010; Siregar et al., 2017; Lee, 1990; Asdak, 1995; Tan, 1990; Wasis, 2012). Land cover by natural forest vegetation in general will have better soil and environmental services than land cover with cultivated crops, and agricultural crops (Lutz and Chandler,

Table1. Biomass in plantation forest, agricultural land and post mining land.

\begin{tabular}{lll}
\hline Cover land & Type of vegetation & Biomass (ton/ha) \\
\hline Plantation forest & Swietenia mahagony & 64.40 \\
Plantation forest & Tectona grandis & 42.22 \\
Agricultural land & Oriza sativa & $0^{*} ;\left(1.354^{* *}\right)$ \\
Post mining land & - & 0 \\
\hline
\end{tabular}

Note: ${ }^{*}$ uncultivated land; ${ }^{* *}$ : Sari et al. (2010)

Table 2. Impact of sand mining on soil physical properties.

\begin{tabular}{llll}
\hline Phisical properties & Agricultural land & Post mining land & Change \\
\hline Bulk Density $\left(\mathrm{g} / \mathrm{cm}^{3}\right)$ & $0.91 \pm 0.04^{*}$ & $1.40 \pm 0.08$ & $+0.49(53.85 \%)$ \\
Porosity (\%) & $65.70 \pm 1.45^{*}$ & $47.44 \pm 2.83$ & $-18.26(27.79 \%)$ \\
Drainage pore (\%) & $15.47 \pm 1.79$ & $9.01 \pm 2.84$ & $-6.46(41.76 \%)$ \\
Permeability $\left(\mathrm{cm} \mathrm{hour}{ }^{-1}\right)$ & $10.51 \pm 0,19$ & $8.93 \pm 5.21$ & $-1.58(15.03 \%)$ \\
\hline
\end{tabular}

\footnotetext{
* significant at $95 \%$ confidence interval.
}

1955; Wasis, 2012; Wasis, 2018). The reclamation of mining land through the reforestation of forest vegetation will be faster to improve soil properties and environmental functions. Field facts show that land reclamation activities carried out at Gumulong Tonggoh are difficult to restore to environmental functions as before (Irwan, 2007; Wasis, 2012; Wasis et al., 2018).

\section{Soil physical properties}

Variables of soil physical properties observed and measured in this study are bulk density, porosity, drainage pore, and permeability. The following are the results of laboratory analysis of the physical properties of soil that have been carried out as presented in Table 2 and Figure 1. Sand mining has caused damage to the physical properties of the soil. The soil damage is a significant increase in bulk density of 0.49 (53.85\%), a marked decrease in porosity of 18.26 (27.79\%). Damage to the physical properties of the soil due to mining activities has caused loss of soil cover vegetation, loss of soil solum (top soil soil layer), loss of clay fraction, damage to soil structure, increased sand fraction and decreased soil organic matter. Damage to the physical properties of the soil will certainly trigger a decrease in fertility and a decrease in environmental functions. Based on soil analysis for permeability parameters ( $8.93 \pm 5.21 \mathrm{~cm} /$ hour), soil damage has occurred because it has exceeded the standard damage criteria (> $8 \mathrm{~cm} /$ hour) according to PP Number 150 of 2000 . Soils that have high bulk density values will has a lower permeability value. Permeability refers to the speed of water in the mass medium. Soils that have fast permeability tend to reduce the ability to store water if the soil has a sandy soil texture.

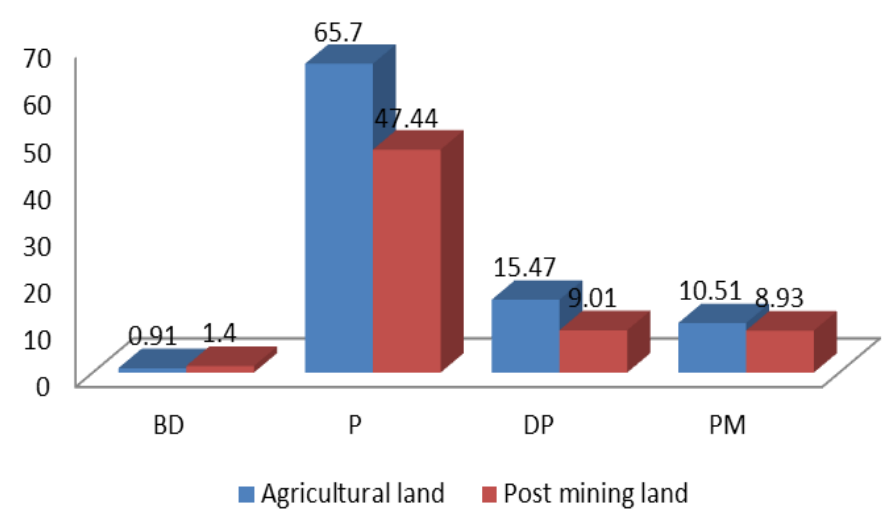

Figure 1. The change of soil physical propertieson natural forest and post mining land. Description : BD (Bulk Density : gram $/ \mathrm{cm}^{3}$ ), PR (Porosiys : \%), DP (Drainage pore: \%), PM (Permeability: $\mathrm{cm} /$ hour). 
Sand grains are usually close to each other to produce high Bulk Density (Soepardi, 1983). In the sand mining location, soil structure instability occurs due to the mining process and soil compaction occurs due to the use of heavy equipment in the mining process which causes the soil pores to become smaller (reduced pore space). Therefore, small porosity causes poor soil aeration and will eventually complicating plant root growth. Soils with a pore space are reduced and the soil weight of each unit increases causing an increase in soil weight. Land with a large weight will be difficult to continue the water or difficult to penetrate the roots of plants, and for the land with low fill weight plant roots are easier to develop (Hardjowigeno, 2007). Soil pores are parts of land that are not filled with solid soil material (filled with air and water). Soil pores can be divided into coarse pores (macro pores) and fine pores (micro pore). Rough pores contain air or gravitational water (water that is easily lost due to gravity), while fine pores contain capillary water and air (Hardjowigeno, 2007). Soil pore space is the part of the land occupied by water and air, while the total pore space consists of space between sand, dust, and clay particles and the space between soil aggregates (Soepardi, 1983).

Pore size and pore stability affect the infiltration power. The bigger and more stable the pore tend to cause bigger infiltration power. Sand soils have more coarse pores than clay. Soil with lots of rough pores makes it hard to hold water so the plants are easy to dry out. Clay has a total pore (number of macro and micro pores) higher than sand soil. Crumb soil provides an infiltration capacity which is greater than clay. Soils with saturated pores have a smaller capacity than the soil in dry conditions. Soil sand has a good drainage pore so that its infiltration is high but it cannot bind the water (Hardjowigeno, 2007). In addition,

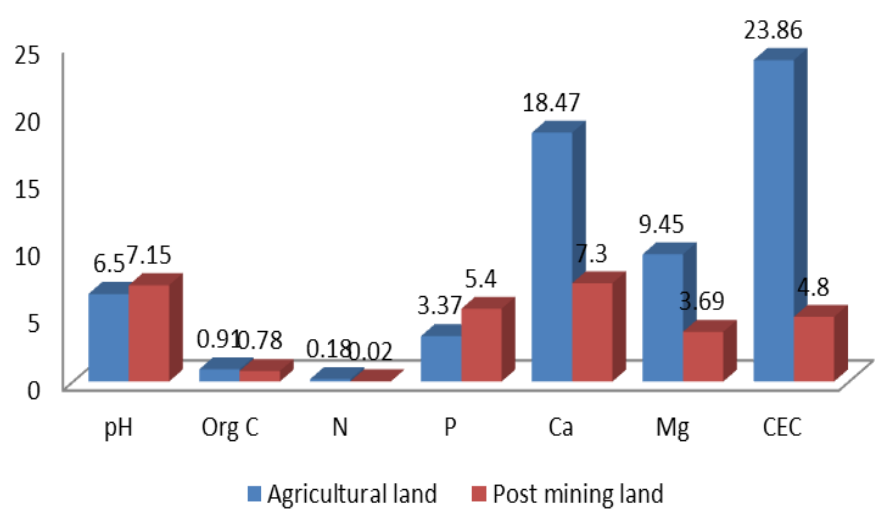

Figure 2. The change of soil chemistry properties on agricultural land and post mining land; Description : $p H(p H)$, organic $C(\%), N$ (Nitrogen : \%), $P$ (Phosphorus : ppm), Ca (calcium : me/100 g), Mg (magnesium : me/100 g), $\mathrm{K}$ (pottasium: me/100 g), $\mathrm{Na}$ (sodium : me/100g). according to Hardjowigeno (2007), soil porosity is influenced by organic matter content, structure, pore size and soil texture. High soil porosity usually has high organic matter. Soils with crumb or granular structures have higher porosity than soils with solid structures. However, the type of soil in the sand soil research location generally has low organic matter and does not have soil structure. Therefore, porosity tends to be smaller. The above has also been emphasized by Foth (1994) that surface soil with sand has smaller porosity than clay (mixed gardens and rice fields have little clay content) meaning that sand soil has less volume occupied by the pore space. Water always moves faster through sand soils than clay. Information for the evidence that seems contradictory is in the size of the pores found in each soil.

\section{Chemical properties of soil}

Soil chemical properties measured and carried out laboratory tests were $\mathrm{pH}$, organic $\mathrm{C}, \mathrm{N}$ total, Phosporus (P) Bray, $\mathrm{Ca}, \mathrm{Mg}$ and CEC. The following are the results of Laboratory analysis which have been presented in Table 3 and Figure 3. Sand mining activities have caused damage to soil chemical properties, namely a significant decrease for Ca of 11.17 (60.48\%), Mg of 5.76 (60.95\%) and CEC of 19.06 (79.88\%). Damage to the chemical properties of the soil is caused by the loss of the top soil layer (horizon A), decreased clay fraction, decreased organic matter and loss of soil cover vegetation as a source of organic material. The low CEC on ex-mining land is triggered by the loss of clay fraction due to washing of clay material and soil erosion. Cation Exchange Capacity (CEC) is a chemical property that is closely related to soil fertility. Soils with high organic matter or clay content have higher CECs than soils with low organic matter or sandy soils (Hardjowigeno, 2007). Soils with organic or high clay content have higher CEC than soil with low organic matter or sandy soil (Hardjowigeno, 2007). This is consistent with the results of research relating to CEC values in postmining locations with high sand content which have a low CEC. Organic levels of $\mathrm{Ca}, \mathrm{Mg}, \mathrm{C}$ and soil $\mathrm{N}$ showed lower values on soil with a sandy soil than on agricultural land. This is caused by loss of vegetation cover and soil solum. The high value of organic $\mathrm{C}, \mathrm{N}, \mathrm{Ca}$ and $\mathrm{Mg}$ on agricultural land comes from the addition of leaf, stem and root tissue to dead plants. The process of deforestation and harvesting of crops tends to cause half of the organic matter of the ecosystem to be lost. In addition, the process of decreasing infiltration rate will cause the falling rain water to cause an increase in runoff and erosion, and increase the loss of organic C, N, Ca, and Mg due to washing and erosion (Wasis, 2006; Hardjowigeno, 2007).

Table 3. Impact of sand mining on soil chemical properties.

\begin{tabular}{|c|c|c|c|}
\hline Chemical properties & Agricultural land & Post mining land & Change \\
\hline $\mathrm{pH}$ & $6.50 \pm 0.10$ & $7.15 \pm 0.05$ & $+0.65(10.00 \%)$ \\
\hline Organic C (\%) & $0.91 \pm 0.78$ & $0.78 \pm 0.13$ & $-0.13(14.29 \%)$ \\
\hline Nitrogen $(\mathrm{N})(\%)$ & $0.18 \pm 0.10$ & $0.02 \pm 0.01$ & $-0.16(88.89 \%)$ \\
\hline Phosphorus (P) (ppm) & $3,37 \pm 0,43^{*}$ & $5,40 \pm 0,50$ & $+2.03(60.24 \%)$ \\
\hline Calcium (Ca) (me $\left.100 \mathrm{~g}^{-1}\right)$ & $18.47 \pm 2.17^{*}$ & $7.30 \pm 2.00$ & $-11.17(60.48 \%)$ \\
\hline Magnesium (Mg) $\left(m e ~ 100 \mathrm{~g}^{-1}\right)$ & $9.45 \pm 1.21^{*}$ & $3.69 \pm 0.68$ & $-5.76(60.95 \%)$ \\
\hline Cation exchange capacity (CEC) (me $100 \mathrm{~g}^{-1}$ ) & $23.86 \pm 1.34^{*}$ & $4.80 \pm 1.73$ & $-19.06(79.88 \%)$ \\
\hline
\end{tabular}

*significant at $95 \%$ confidence interval. 


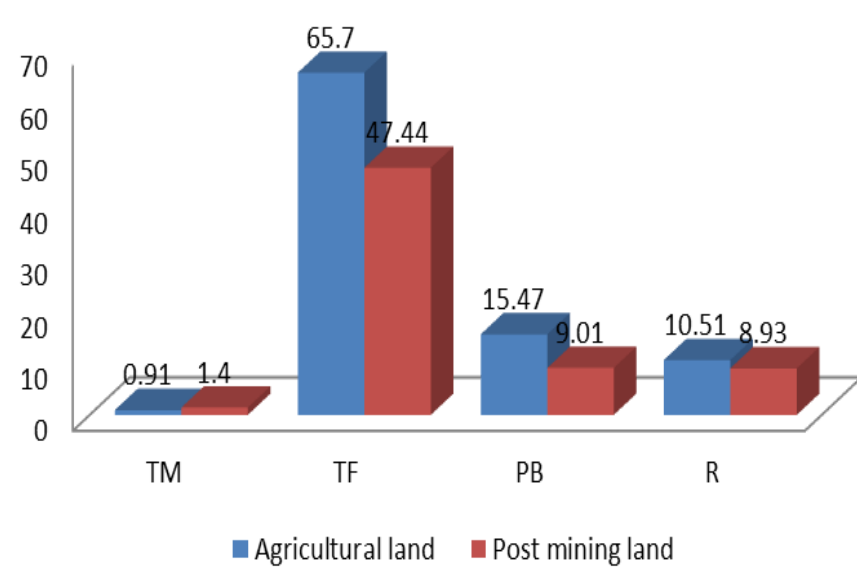

Figure 3. The change of soil biological properties on agricultural land and post mining land; Description : TM (total microorganisms: $\times 10^{6} \mathrm{cpu}$ ), TF (total fungi : $\left.\times 10^{4} \mathrm{cpu}\right), \mathrm{PB}\left(\mathrm{P}\right.$ dissolving bacteria : $\times 10^{3} \mathrm{cpu}$ ) and $R$ (respiration : $\mathrm{mgC}-\mathrm{CO}_{2} / \mathrm{kg}$ soil /day).

\section{Biological properties of soil}

The biological properties of soil measured and carried out by laboratory tests were total microorganisms, total fungi, $P$ dissolving bacteria and respiration. The following are the results of laboratory analyzes that have been carried out as presented in Table 4. Sand mining has caused damage to the biological properties of the soil, which is a significant decrease in total microorganisms by 47.00 (83.19\%). Damage to soil biological properties for total fungi parameters and total $\mathrm{P}$ dissolving bacteria occurs, where there are no microbes in the former mine soil samples. The results showed that sand mining has caused damage to the biological properties of the soil. Damage to the biological properties of the soil is caused by loss of vegetation cover, loss of solum and soil organic matter (Wasis et al., 2018). Life in the world starts from microorganisms, both heterotropic and muscropic. Plant roots absorb nutrients and leaves absorb energy, producing organs consumed by animals / humans and forming their organs. The death organs or waste are consumed and overhauled by microorganisms again into nutrients and energy. The land is inhabited by a variety of soil microorganisms. The number of each group of microorganisms reaches millions per gram of soil. The number of microorganisms is very useful to determine the location of microorganisms in relation to the root system, the residual organic matter and the depth of the soil profile related to soil fertility (Anas, 1989; Hanafiah, 2007).

\section{Economic valuation of the environment damage}

Based on the results of field research, laboratory analysis and Environmental Ministry Economic Valuation Guidelines (2006), the economic valuation of soil and environmental damage due to sand mining in the Gumulung Tonggoh Village in Astanajapura, Cirebon District, West Java Province, covering 2 ha can be calculated as follows (KLH, 2006 ; Wasis, 2006; Adamowicz and Boxall, 2001; Fauzi, 2014; Vranken et al., 2013).

\section{Analysis of environmental losses}

Costs of turning on the water function

The cost of restoration of the water system as a result of damage to land in secondary forests, mixed gardens and shrubs (control) with the construction of the reservoir must have the ability to store water (control) of $401 \mathrm{~m}^{3} /$ ha (Available water content: $20.05 \pm 0.58 \%$ ) a building size: $15 \mathrm{~m} \times 20 \mathrm{~m} \times$ long 1.5 $\mathrm{m}$ is needed (correction factor capacity $=0.89 \pm 0.11$ ). Reservoir development costs are assumed per $\mathrm{m}^{2}=\mathrm{Rp}$. 100,000 . A hectare of damaged land requires a fee of $[(2 \times 1.5 \mathrm{~m}$ $\times 15 \mathrm{~m})+(2 \times 1.5 \mathrm{~m} \times 20 \mathrm{~m})+(15 \mathrm{~m} \times 20 \mathrm{~m})] /$ ha $\times$ Rp. $100,000 /$ $\mathrm{m}^{2}=405 \mathrm{~m}^{2} /$ ha $\times$ Rp. $100,000 / \mathrm{m}^{2}=$ IDR 40,500,000 / ha and for mixed garden and agricultural areas lost due to destruction of land and vegetation of 2 ha, the costs of making and maintaining are 2 ha $\times$ Rp. 40,500,000 / ha $\times 100$ year which equals to Rp. $8,100,000,000$.

\section{Water management arrangement}

The cost of regulating water based on the benefits of water for cultivation purposes is Rp. 22,810,000 / ha. The cost needed to arrange the water system for 2 ha $=2$ ha $\times R p 22,810,000 /$ ha is Rp. 45,620,000.

\section{Erosion and runoff control}

The cost of erosion control and runoff with the construction of terraces, ridges and rorak is equal to Rp. 6,000,000 / ha. Costs needed for erosion control and runoff of 2 ha are: 2 ha $\times$ Rp. $6,000,000 /$ ha $=$ Rp. $12,000,000$.

\section{Land formation}

The cost of land formation due to damaged land is Rp. 500,000 / ha. The cost needed for the formation of a land area of 2 ha damaged is: 2 ha $\times$ Rp. 500,000 / ha = Rp. 1,000,000.

\section{Nutrient recycling}

The cost of recycling nutrients lost due to soil damage is $\mathrm{Rp}$. $4,610,000$ per ha. The cost for recycling 2 ha of nutrients is 2 ha $\times$ Rp. $4,610,000=$ Rp. $9,220,000$.

Table 4. Impact of sand mining on soil biological properties.

\begin{tabular}{llll}
\hline Biological properties & Agricultural land & Post mining land & Change \\
\hline Total microorganisms $\left(\times 10^{6} \mathrm{cpu}\right)$ & $56.50 \pm 0.50^{*}$ & $9.50 \pm 0.08$ & $-47.00(83.19 \%)$ \\
Total fungi $\left(\times 10^{4} \mathrm{cpu}\right)$ & $2.25 \pm 2.25$ & $0.50 \pm 0.50$ & $-1.75(77.78 \%)$ \\
P dissolving bacteria $\left(\times 10^{3} \mathrm{cpu}\right)$ & $11.50 \pm 3.50$ & $0.50 \pm 0.50$ & $-11.00(95.65 \%)$ \\
Respiration $\left(\mathrm{mgC}-\mathrm{CO}_{2} / \mathrm{kg}\right.$ soil $/$ day $)$ & $13.03 \pm 0.52$ & $10.84 \pm 0.47$ & $-2.19(16.81 \%)$ \\
\hline
\end{tabular}

"significant at $95 \%$ confidence interval. 
Waste decoder

The cost of decomposing waste lost due to soil damage is $\mathrm{Rp}$. 435,000 per ha. The cost needed for decomposing waste area of 2 ha is 2 ha $\times$ Rp. $435,000 /$ ha $=$ Rp. 870,000 .

\section{Biodiversity}

The cost of biodiversity loss due to land damage is Rp. 2,700,000 per ha. The cost needed for biodiversity is 2 ha $\times \mathrm{Rp} .2,700,000=$ Rp. 5,400,000.

\section{Genetic resources}

The cost of genetic resources loss due to land damage is $\mathrm{Rp}$. $410,000 /$ ha. The cost required for an area of 2 ha is: 2 ha $\times$ Rp. 410,000, - = Rp. 820,000.

\section{Carbon release}

The cost of removing carbon due to land damage is $\mathrm{Rp}$. $32,310,000 /$ ha. Costs incurred covering an area of 2 ha are 2 ha $\times$ Rp. 32,310,000 / ha = Rp. 64,620,000.

\section{Loss of soil, sand and stone material}

The cost of soil, sand and stone material in a mixed conservation and agriculture area with the volume of land, sand and stone for the volume of $120,000 \mathrm{~m}^{3}$. Soil, sand and stone material costs Rp. $50,000 / \mathrm{m}^{3}$. The cost of loss of soil, sand and stone material is $120,000 \mathrm{~m}^{3} \times$ Rp. $50,000 / \mathrm{m} 3=$ Rp. $6,000,000,000$.

\section{Disadvantages of environmental economics}

In the part of environmental economic damage, there is $2 \times$ $8,000 \mathrm{Kg} \times \mathrm{Rp} \mathrm{2,000/Kg}=\mathrm{Rp} .32,000,000 /$ ha loss. Total of conomic losses in 2 ha for 100 years, namely: 2 ha $\times$ Rp. $32,000,000$ / ha $\times 100$ years is Rp. $6,400,000,000$.

\section{Environmental recovery costs}

The cost of restoring the environment to activate the lost ecological function is:

a. Water supply through reservoir construction $=\mathrm{Rp}$. 8,100,000,000

b. Control of runoff and erosion = Rp. 12,000,000

c. Land formation $=$ Rp. $1,000,000$

d. Nutrient recycling $=$ Rp. 9,220,000

e. Decomposition of waste $=$ Rp. 870,000

f. Biodiversity = Rp. 5,400,000

g. Genetic Resources $=$ Rp. 820,000

h. Carbon release $=$ Rp. 64,620,000

i. Returns of land, sand and natural stones $=$ Rp. 6,000,000,000

Total (a - i) is Rp. 14,193,930,000

The total cost of environmental damage due to sand mining are ecological damage + economic loss + environmental recovery, which are Rp. 18,755,930,000 + Rp. 6,400,000,000 + Rp. $14,193,930,000$, which equals to Rp. 39,349,860,000.

\section{Conclusion}

This investigation concluded that the sand mining activities trigger soil and environmental damage to the soil (soil solum, bulk densituy, permeability, and soil fauna) and vegetation (land cover). In addition, sand mining has caused changes in soil properties, namely a significant increase in Bulk density of +0.49 (53.85\%), reduction in porosity of 18.26 (27.79\%), decrease in Ca of -11.17 (60.48\%), a decrease in $\mathrm{Mg}$ of -5.76 (60.95\%), a decrease in CEC of -19.06 (79.88\%) and a decrease in the total microorganism of 47.00 (83.19). The total results from the economic valuation of the cost of environmental damage due to sand mining are Rp. 39,349,860,000. Thus, sand mine caused a significant environmental damage in the Gumulung Tonggoh, Cirebon District, West Java Province of Indonesia.

Open Access: This is an open access article distributed under the terms of the Creative Commons Attribution 4.0 License, which permits unrestricted use, distribution, and reproduction in any medium, provided the original author(s) if the sources are credited.

\section{REFERENCES}

Adamowicz, V. and Boxall, P. (2001). Future Directions of Stated Choice Methods for EnvironmentValuation. Vic Adamowicz and Peter Boxall. Choice Experiments: A New Approach to Environmental Valuation, April 10, 2001. London, England

Anas, I. (1989). Petunjuk Laboratorium: Biologi Tanah dalam Praktek. Bogor: Departemen Pendidikan dan Kebudayaan. Pusat Antar Universitas Bioteknologi. Institut Pertanian Bogor.

AOAC (2005). In: Official methods of analysis of the association of official analytical chemists. 13th edition, pp.545-567.

Dumairy. (1992). Ekonomika Sumberdaya Air: Pengantar ke Hidronomika. BPFE Yogyakarta, pp. 222.

Fauzi, A. (2014). Valuasi Ekonomi dan Penilaian Kerusakan Sumberdaya Alam dan Lingkungan. PT Penerbit IPB Press, pp. 246.

Foth, H. D. (1994). Dasar-dasar Ilmu Tanah. PT Erlangga. Jakarta.

Hanafiah, K.A. (2005). Dasar-dasar Ilmu Tanah. PT Raja Grafindo Persada. Jakarta.

Hardjowigeno, S. (2007). Ilmu Tanah. Akademika Pressindo. Jakarta.

Irwan, Z. D. (2007). Prinsip-prinsip Ekologi, Ekosistem, Lingkungan dan Pelestariannya. Penerbit Bumi Aksara Jakarta. P 210.

Kusmana, C. and Istomo. (1995). Forest Ekology. Faculty of Forestry IPB, Bogor, pp. 190.

Kusumadewi, F. (2012). Analisa karbon terikat di atas permukaan tanah pada tegakan pohon mahoni dan jati di lahan reklamsi bekas tambang pasir Gumulong Tonggoh 
Kabupaten Cirebon, Jawa Barat. Tesis. Sekolah Pascasarjana IPB. Bogor.

Laar, A. V. and Akca, A. (1997). Forest Mensuration. Cuvillier Verlag Gotingen. pp. 418.

Lutz, H. J., and Chandler, R. F. (1965). Forest Soil. John Wiley \& Sons, Inc. New York.

Mattjik, A.A. and Sumertajaya, I.M. (2013). Experimental Design with SAS Applications and Minitab. IPB Press, Bogor.

Sari, D.K., Ismullah, I. H., Sulasdi, W. N., dan Harto, A.B. (2010). Estimasi Produktivitas Padi Sawah Berbasis Kalender Tanam Heterogen Menggunakan Teknologi Pengindraan Jauh Wilayah Studi: Jawa Barat Bagian Utara. Jurnal Rekayasa Institut Teknologi Nasional XIV (3) : 110-124.

Soepardi, G. (1983). Sifat dan Ciri Tanah. Jurusan IImu Tanah Fakultas Pertanian IPB. Bogor.

Soerianegara, I. and Indrawan A. (2005). Indonesian Forest Ecology. Department of Forest Management, Faculty of Forestry IPB, Bogor.

Stell, R.G.D. and Torries, J.H. (1991). Statistical Principles and Procedures, A Biometric Approach. PT Gramedia Pustaka Utama Jakarta, pp. 149-167.

Tan, K.H. (1995). Enviromental Soil Science. Marcel Dekkker Inc. New York, pp. 255.

Vranken, L., Turnhout, P.V., Eeckhaut, M.V.D., Vandekerckhove, L. and Poesen, J. (2013). Economic valuation of landslide damage in hilly regions: A case study from Flanders, Belgium. Science of the Total Environment, 447: 323-336.

Wasis, B., Arifin and Winata, B. (2018). Impact of bauxite mine to natural forest biomass and soil properties in Kas Island, Riau Island Province in Indonesia. Archives of Agriculture and Enviromental Science, 2(3): 238-243.

Wasis, B. (2006). Comporison of site quality between first rotation and second rotation Acacia mangium plantation forest (A Case study in Industrial plantation forest of PT Musi Hutan Persada, South Sumatra Province). Disertation: Bogor Agricultural University (IPB). Bogor.

Wasis, B. (2012). Soil properties in natural forest destruction and cconversion to aagricultural land in Gunung Leuser National Park, North Sumatera Province. Journal of Tropical Forest Management (JMHT), XVIII(3): 206-212

Wasis, B. and Andika, A. (2017). Growth response of mahagony seedling (Swietenia macrophylla King.) to addition of coconut shell charcoal and compost on ex-sand mining site of West Java Province in Indonesia. Archives of Agriculture and Enviromental Science, 2(3): 238-243.

Wasis, B. and Fathia, N. (2011). Growth of gmelina seedlings with various doses of compost fertilizers on the media of former ground gold mine. Journal of Tropical Forest Management, 17 (1): 29-33.

Wasis, B., Setiadi, Y., and Purwanto, M.E. (2012). Perbandingan Sifat Kimia Tanah dan Biologi Tanah akibat Keterbukaan Lahan pada Hutan Reboisasi Pinus di Kecamatan Pollung Kabupaten Humbang Hasudutan, Sumatera Utara. Jurnal Silvikultur Tropika, 03(01): 33 - 36

Wibisono, Y. (2009). Metoda Statistik. Method. Gadjah Mada University Press. Yokyakarta, pp. 529-603. 